\section{Annual of the Astronomical Observatory, Madrid}

THE receipt of the usual annual astronomical handbook from Madrid ("Anuario del Observatorio Astronómico de Madrid") in the unusual circumstances that exist to-day in Spain, calls for at least a brief comment. The 1937 handbook contains current tabular matter that is likely to be of general use to observers in Spain-astronomical elements, tables of sunrise and sunset and of moonrise and moonset (in each case for Madrid), planetary phenomena, solar and lunar eclipses, positions of the principal nebulæ and double stars, etc. A set of monthly charts is included to illustrate the night-skies as seen by an observer at Madrid, and a concluding chapter de. scribes the use of wireless time-signals for the dissemination of standard time and the application of the signals to longitude determinations.

\section{Société Astronomique de France (1887-1937)}

THIs year, the Société Astronomique de France celebrates its fiftieth anniversary, and the January issue of $L$ 'Astronomie recounts the circumstances of its inception on January 28, 1887, owing chiefly to the efforts of M. Camille Flammarion. The aim of the new society was to foster in France an interest in astronomy and to establish a link mainly between non-professional astronomers in all parts of the country. The society now has a membership of 5,000 , and includes astronomers from many countries ; it possesses an observatory in Paris which members may use, and records its regular meetings and general activities as well as publishing papers in its monthly periodical, L'Astronomie. We welcome this opportunity of extending our congratulations.

\section{The Pasteur Institute of Southern India}

MaJor IYengar, director of the Pasteur Institute of Southern India, Coonoor, has issued his annual report for the year ended March 31, 1936. The number of patients who underwent a full course of treatment at the Institute was 433 , and 102 patients received incomplete treatment for various reasons. There were no deaths from hydrophobia among those treated at the Institute. In addition, more than 14,000 courses of antirabic vaccine were issued to outlying centres. Details of the course of treatment are given; Semple's carbolized 5 per cent sheep vaccine was in use throughout the year, prepared from Paris fixed virus.

\section{Announcements}

Prof. Heinrich Wieland, professor of chemistry at Munich, has been elected a corresponding member of the Physico-Mathematical Section of the Prussian Academy of Science.

SIR HARRY LINDSAY, director of the Imperial Institute, has been nominated as president of the Association of Special Libraries and Information Bureaux, (ASLIB), for the year 1937-38. The Association will hold its fourteenth Annual Conference at Gonville and Caius College, Cambridge, during the week-end beginning September 24. Particulars may be obtained from the Secretary of the Association, 31 Museum Street, London, W.C.1.

Mr. T. G. Rose has been appointed general director of the National Institute of Industrial Psychology, to collaborate with Dr. C. S. Myers, the principal, who will retain the position held by him since the inception of the Institute sixteen years ago.

LORD SNELL will open the Studio of Animal Art in the Zoological Gardens of the Zoological Society of London, Regent's Park, N.W.8, on April 21 at 2.30 .

A Bust of Prof. Babes, founder of the first Pasteur Institute in Bucharest, who died ten years ago, was recently unveiled in Bucharest, when memorial addresses were delivered by Profs. Bacalogliu, Ciuca, Manicatide, Marinesco and Proca.

ThE thirty-ninth annual conference of the Institute of Public Cleansing will be held at Margate from June 14-18. Further information can be obtained from the honorary secretary of the Institute, 160 Buckingham Palace Road, S.W.I.

AN International Conference on "Esperanto in Modern Life" will be held in Paris on May 14-17. Participation in the Conference is free. Further information can be obtained from the secretariat, Conférence Internationale (L'Esperanto dans la Vie Moderne), 34 Rue de Chabrol, Paris, $10^{\mathrm{e}}$.

THE thirty-fifth annual session of the South African Association for the Advancement of Science will be held at Windhoek, South-West Africa, under the presidency of Lieut.-Colonel C. Graham Botha, on July 5-10. Further information can be obtained from Dr. C. F. Juritz, Department of Agriculture, P.O. Box 3, Capetown.

A commixtee has been formed by the French Air Ministry to deal with the requirements of the air force and to secure the best possible adaptation of the human organism for military aerial navigation. The functions of the committee will be first to express opinions on biological and medical problems brought before it by the Air Minister, and secondly to supply the Minister with useful suggestions regarding biological questions relating to military aviation.

THE triennial award of the Coopers Hill War Memorial Prize and Medal will be made this year by the Institution of Electrical Engineers, which invites members to submit for consideration a paper on any subject coming within the scope of electrical science or electrical engineering and their applications. Further information can be obtained from the Secretary, Institution of Electrical Engineers, Savoy Place, Victoria Embankment, London, W.C.2. 